\section{Fraser Fir Tolerance and Weed Control with Hexazinone + Sulfometuron-methyl}

\author{
Linglong Wei, Jarrod J. Morrice, Rodney V. Tocco, \\ and Bernard H. Zandstra ${ }^{1}$
}

AdDitionAl INDEX wORDs. Christmas trees, flumioxazin, simazine, oryzalin, paraquat, oxyfluorfen

Summary. Experiments were conducted to test a new herbicide for posttransplant application in Christmas trees. A premix containing $68.6 \%$ hexazinone and $6.5 \%$ sulfometuron-methyl was applied at 3.0, 4.5, 6.0, 7.5, and 9.0 oz/acre plus $0.25 \%$ $\mathrm{v} / \mathrm{v}$ nonionic surfactant (NIS) to recently transplanted fraser fir (Abies fraseri) Christmas trees and trees transplanted for 1 year in Spring 2008. The treatments were repeated on the same plots in 2009 and 2010. At Gobles, MI, trees treated with $7.5 \mathrm{oz} /$ acre of hexazinone plus sulfometuron had increased stem diameter, after one growing season, and trees treated with $9.0 \mathrm{oz} /$ acre had reduced leader length the second year. After 3 years, fraser fir trees treated with hexazinone plus sulfometuron at $9.0 \mathrm{oz} /$ acre had reduced tree height. Stem diameter, leader length, and number of leader buds were not statistically different from the untreated control. At Horton, MI, trees treated with $9.0 \mathrm{oz} /$ acre of hexazinone plus sulfometuron had reduced leader length after 1, 2, and 3 years. After 3 years, trees treated with hexazinone plus sulfometuron at $6.0,7.5$, and $9.0 \mathrm{oz} /$ acre were shorter than the untreated controls. There were no differences from the untreated trees in stem diameter of trees treated with hexazinone plus sulfometuron after 3 years.

$\mathrm{R}$ ecently transplanted Christmas trees are susceptible to weed competition and herbicide injury. Traditional herbicide programs for recent transplants and established trees have included the photosystem II (PSII) inhibitors atrazine and simazine [Lantagne and Koelling, 1997; Neal et al., 1999; U.S. Department of Agriculture (USDA), 2004; White and Newton, 1990]. Repeated use of PSII inhibitors and other longresidual herbicides has resulted in the development of herbicide resistance in several weed species and an increase in numbers of weeds that are naturally tolerant of these herbicides (Gower et al., 2004; Peachey et al., 201l; Richardson and Zandstra, 2006). Regardless of resistance problems, chemical weed control is essential for profitable and successful Christmas tree production (Ahrens and Newton, 2008; Brown et al., 1989).

New herbicides for long-term weed control have been developed by the chemical industry, and these herbicides need to be evaluated for their safety in Christmas tree production

Department of Horticulture, Michigan State University, 1066 Bogue Street, Room 440, Plant and Soil Science Building, East Lansing, MI 48824

This research was supported by Michigan AgBioResearch and Project GREEEN, Michigan State University.

${ }^{1}$ Corresponding author. E-mail: zandstra@msu.edu. and weed control effectiveness. Westar 75 DG (DuPont Corp., Wilmington, $\mathrm{DE}$ ) is a combination of $68.6 \%$ hexazinone, a photosynthesis inhibitor, and $6.5 \%$ sulfometuron-methyl, an acetolactate synthase inhibitor (DuPont Corp., 2009). It is an effective herbicide providing both contact and residual control of many annual and perennial weeds (Martin et al., 2004). The label allows hexazinone plus sulfometuron to be broadcast over dormant 4-year-old trees that have been established in the field for at least 1 year. Preliminary research in the northeastern United States indicated that there was potential for needle burn with hexazinone plus sulfometuron, especially at high rates (Kuhns and Harpster, 2005; Martin et al., 2004). Hexazinone (Velpar, DuPont Corp.) is registered for use in Christmas trees. Sulfometuron (Oust XP, DuPont Corp.) is not labeled for Christmas trees but is labeled for conifer release in forestry plantations. Both herbicides provide excellent broad-spectrum weed control, but have potential for conifer injury (Rose and Ketchum, 2004; Seifert and Woeste, 2002).

Many weeds emerge in Christmas tree plantations (Richardson and Zandstra, 2009). Perennial and biennial weeds, along with invasive and persistent annuals predominate. In these experiments, the most common weeds were common ragweed (Ambrosia artemisiifolia), horseweed (Conyza canadensis), hoary alyssum (Berteroa incana), rabbitfoot clover (Trifolium arvense), and quackgrass (Elymus repens). Common ragweed and horseweed are annuals in the Asteraceae family, which tolerate many preemergence herbicides and germinate during the entire season. Rabbitfoot clover is an annual that inhabits sandy and rocky soils. Hoary alyssum is a perennial in the mustard family that inhabits sandy and gravelly soil. Quackgrass is a perennial on many types of soils (Muenscher, 1935).

The effects of repeated applications of the combination of hexazinone plus sulfometuron on fraser fir have not been reported. Therefore, these experiments were conducted to determine tolerance of recently transplanted and 1-year-transplanted fraser fir to hexazinone plus sulfometuron and to compare it with other Christmas tree herbicides for weed control effectiveness and crop safety.

\section{Materials and methods}

Experiments were established on grower farms in Gobles and Horton, MI. At Gobles, 3-year-old (plug plus 2 years) fraser fir seedlings were planted in the field on 18 Apr. 2008. The trees were 10-12 inches tall at transplanting. Each plot consisted of three rows with six to eight trees per row. There were $6 \mathrm{ft}$ between rows and
To convert U.S. to SI, multiply by

\begin{tabular}{clll} 
multiply by & U.S. unit & SI unit & multiply by \\
\hline 0.3048 & $\mathrm{ft}$ & $\mathrm{m}$ & 3.2808 \\
9.3540 & gal/acre & $\mathrm{L} \cdot \mathrm{ha}^{-1}$ & 0.1069 \\
2.54 & inch $(\mathrm{es})$ & $\mathrm{cm}$ & 0.3937 \\
25.4 & inch $(\mathrm{es})$ & $\mathrm{mm}$ & 0.0394 \\
1.1209 & lb/acre & $\mathrm{kg} \cdot \mathrm{ha}^{-1}$ & 0.8922 \\
1.6093 & $\mathrm{mph}$ & $\mathrm{km} \cdot \mathrm{h}^{-1}$ & 0.6214 \\
70.0532 & $\mathrm{oz} / \mathrm{acre}$ & $\mathrm{g} \cdot \mathrm{ha}^{-1}$ & 0.0143 \\
6.8948 & $\mathrm{psi}$ & $\mathrm{kPa}$ & 0.1450 \\
$\left({ }^{\circ} \mathrm{F}-32\right) \div 1.8$ & ${ }^{\circ} \mathrm{F}$ & ${ }^{\circ} \mathrm{C}$ & $\left({ }^{\circ} \mathrm{C} \times 1.8\right)+32$
\end{tabular}

To convert SI to U.S.,

$\left({ }^{\circ} \mathrm{C} \times 1.8\right)+32$ 
$5 \mathrm{ft}$ between trees in rows. The soil was an Oshtemo sandy loam (coarseloamy, mixed, mesic Typic Hapludalfs) with $81 \%$ sand, $14 \%$ silt, $4 \%$ clay, $1.4 \%$ organic matter, and $\mathrm{pH} 6.3$.

The Gobles site is in USDA hardiness zone $6 \mathrm{a}$, with average extreme low air temperatures of -10 to $-5{ }^{\circ} \mathrm{F}$ and average spring frost-free day of 1 June. Maximum/minimum temperatures for 2008, 2009, and 2010 were $92.9 /-4.2,95.3 /-2.4$, and 93.4/-2.4 ${ }^{\circ} \mathrm{F}$, respectively. Annual/ growing season (April-October) precipitation at Gobles for 2008-10 was $37.35 / 26.26,28.13 / 16.78$, and $30.87 / 25.90$ inches, respectively (Michigan State University, 2013). The Horton site is in USDA hardiness zone $5 \mathrm{~b}$, with average extreme low air temperatures of -15 to $-10^{\circ} \mathrm{F}$ and average spring frost-free day of 1 June. Maximum/minimum temperatures for 2008,2009 , and 2010 were $98.5 /-7.5,94.9 /-30.3$, and $95.5 /-9.0^{\circ} \mathrm{F}$, respectively (Michigan State University, 2013). Yearly/ growing season (April-October) precipitation at Horton for 200810 was $35.32 / 24.26,33.30 / 24.39$, and $28.75 / 24.11$ inches, respectively (Michigan State University, 2013).

At Gobles, the herbicide treatments were broadcast over the top of the plants on 23 Apr. 2008, 12 May 2009, and 20 Apr. 2010; all treatments were applied before budbreak. Hexazinone plus sulfometuron was applied at $4.5,6.0,7.5$, or $9.0 \mathrm{oz} /$ acre plus $0.25 \%$ NIS. Additional treatments were $4.1 \mathrm{oz} /$ acre flumioxazin (SureGuard 51 WG; Valent USA, Walnut Creek, CA) plus $0.25 \%$ NIS; $4 \mathrm{lb} /$ acre simazine (Princep Caliber 90; Syngenta Crop Protection, Greensboro, NC) plus $3 \mathrm{lb} /$ acre oryzalin (Surflan 4 AS; United Phosphorus Inc., Trenton, NJ) plus $1 \mathrm{lb} / \mathrm{acre}$ paraquat (Gramoxone Inteon; Syngenta Crop Protection) plus $0.25 \%$ NIS; $2 \mathrm{lb} /$ acre pronamide (Kerb 50 WP; Dow AgroSciences, Indianapolis, IN) plus $1 \mathrm{lb} /$ acre oxyfluorfen (GoalTender 4 SC, Dow Agrosciences) plus $0.25 \%$ NIS; and an untreated control. Herbicide rates were selected based on label recommendations for soil type.

The aisles between the trees were mowed each spring before application to remove dead weeds from the previous growing season. Herbicides were applied in a $5.3-\mathrm{ft}$ band with a carbon dioxide $\left(\mathrm{CO}_{2}\right)$-pressurized backpack sprayer with four flat fan nozzles (TeeJet XR 8002; Spraying Systems, Wheaton, IL) spaced 16 inches apart, delivering $20 \mathrm{gal} /$ acre at $30 \mathrm{psi}$ pressure and $3.2 \mathrm{mph}$ walking speed. The experiment was designed as a randomized complete block with three replications. The field was not irrigated.

At Horton, 3-year-old fraser fir trees (plug +2 years) were planted in the field on 1 Apr. 2007. The herbicide experiment was established the following year on 5 May 2008. Subsequent treatments were made on 11 May 2009 and 21 Apr. 2010. Each plot contained four rows with five to six trees per row. The rows were $6 \mathrm{ft}$ apart and trees were spaced $5.5 \mathrm{ft}$ apart within rows. The soil was a Boyer-Oshtemo sandy loam (coarseloamy, mixed, mesic Typic Hapludalfs) with $77 \%$ sand, $15 \%$ silt, $7 \%$ clay, $1.4 \%$ organic matter, and $\mathrm{pH} 6.0$. The experiment was arranged as a randomized complete block design with four replications. Hexazinone plus sulfometuron was applied at 3.0, 4.5, 6.0, 7.5 , and $9.0 \mathrm{oz} /$ acre. The $3.0-\mathrm{oz} /$ acre rate was added because of space availability. The other herbicide treatments and application methods were the same as those used at Gobles. The field was not irrigated.

The fraser fir trees and weeds were evaluated visually during the summer each year. Trees were rated on an injury scale $(1-10)$, where 1 represents no crop injury and 10 represents tree death. The rating scale of 1 to 10 is based on several factors, including tree height, vigor, needle color, stand, and overall conditions. Thus, $1=$ plants with $0 \%$ to $10 \%$ injury, 2 = plants with $11 \%$ to $20 \%$ injury, and so forth. Trees rated $1-3$ are in overall good condition; trees rated 4-6 have moderate injury of some type; and trees rated 7-10 have serious injury and may not survive or grow out of the injury. Weeds were rated by the amount of control each herbicide treatment provided for each species present in the plot; $1 \%$ represents no weed control and $100 \%$ represents complete control. Weed density, height, and vigor were included in the weed ratings. In September or October each year, leader length and plant height were measured with a meter stick. Tree stem diameter at 1 to 2 inches above soil level was measured with a digital vernier caliper (Mitutoyo America Corp., Aurora, IL). Diameter measurements were taken in two directions and averaged for each tree. In fall of the third year (2010), the buds on the leaders were counted. All trees in each plot were measured for all parameters, and means were calculated for each plot.

All data were subjected to repeated measures analysis of variance using a generalized linear mixed effects model (PROC GLIMMIX) in SAS (version 9.2; SAS Institute, Cary, NC). Weed ratings, fraser fir injury ratings, and the number of leader buds were analyzed with a Poisson distribution (Ott and Longnecker, 2001) using an identity link except for the weed ratings of hoary alyssum, which required a log link (SAS Institute, 2008). Overdispersion was found in some Poisson models and was accounted for using a multiplicative overdispersion factor (SAS Institute, 2008). Tree measurements of height, stem diameter, and leader length were analyzed with a normal distribution. Assumptions of normality were checked using diagnostic plots. Height, diameter, and Gobles leader length measurements were inverse transformed. No transformation was needed for the leader length measurements at Horton. Akaike's information criterion was used to compare correlation structures (Akaike, 1974). Tukey's post hoc test was used to compare treatment means against the untreated control for each time point with a significance level $(\alpha)$ of 0.05 . Where necessary, results have been back transformed and presented in original units.

\section{Results and discussion}

EFFECT OF HERBICID E TREATMENTS ON FRASER FIR. At Gobles, fraser fir in all treatments had some needle burn and stunting in Aug. 2008 (Fig. 1). Trees treated with $9.0 \mathrm{oz} /$ acre of hexazinone plus sulfometuron and pronamide plus oxyfluorfen at Gobles were similar to the controls in condition, with ratings close to 6 . The untreated trees were stunted from weed competition. Trees treated with lower rates of hexazinone plus sulfometuron, flumioxazin, and simazine plus oryzalin plus paraquat at Gobles in 2008 had less visual injury than the controls. In 


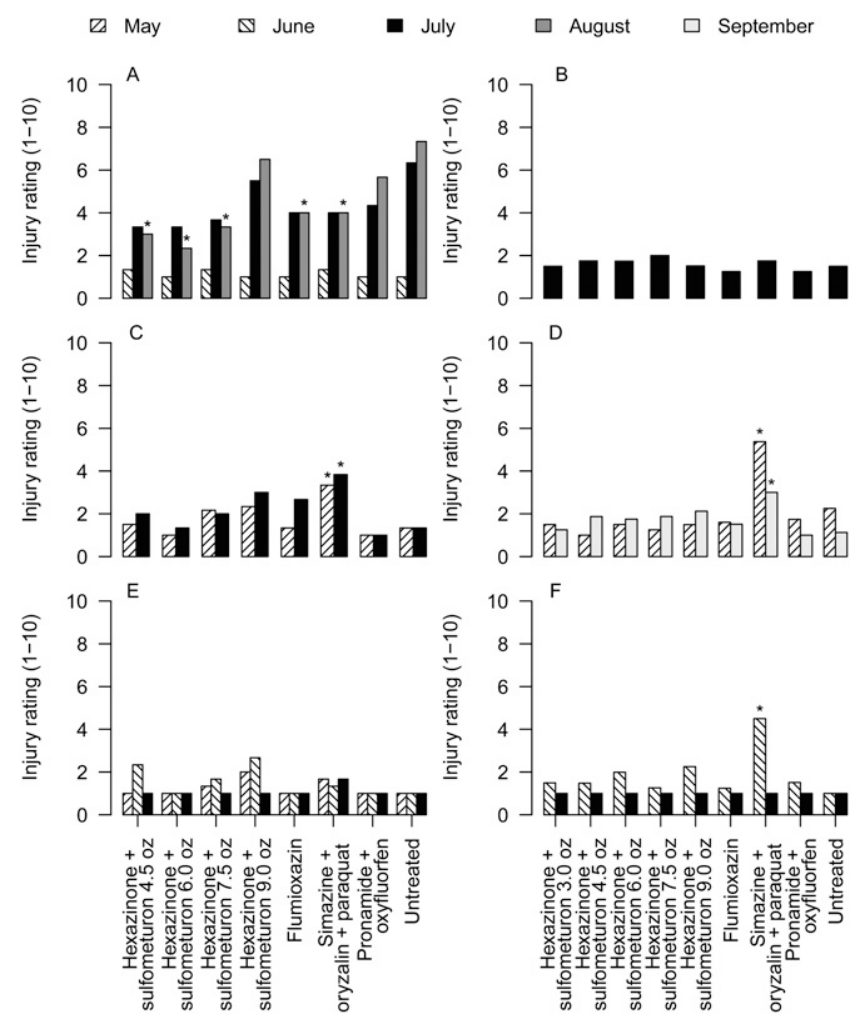

Fig. 1. Herbicide injury ratings for fraser fir trees at Gobles, MI (A, C, and E) and Horton, MI (B, D, and F) for the years 2008 (A and B), 2009 (C and D), and 2010 ( $E$ and $F)$. Ratings were conducted on a scale from 1 to 10 with 1 representing no damage to the tree and 10 representing complete death of the tree. Bar patterns indicate the month that the weed rating was conducted. Application rates for hexazinone plus sulfometuron treatments are in ounces per acre. Each bar is the modeled value from three replicates at Gobles $(n=3)$ and four replicates at Horton $(n=4)$. Asterisks indicate that a treatment is significantly different from the untreated control for that specific rating $(P \leq 0.05)$. Significant differences were obtained using Tukey's post hoc test; $1 \mathrm{oz} /$ acre $=70.0532 \mathrm{~g} \cdot \mathrm{ha}^{-1}$.

2008 at Horton, fraser fir had no significant visual injury in July from any treatment compared with the control. At both sites, visual injury was greater on the trees treated with simazine plus oryzalin plus paraquat in 2009. In 2010, trees treated with simazine plus oryzalin plus paraquat continued to have significantly higher visual injury in early June at Horton, but that treatment was not different from the untreated at Gobles.

There were few differences in tree vigor compared with the untreated control at Gobles (Fig. 2). Trees treated with hexazinone plus sulfometuron at $7.5 \mathrm{oz} /$ acre had slightly larger stem diameters than the untreated controls in Fall 2008 but were similar to the untreated trees and other treatments in 2009 and 2010 . Trees treated with hexazinone plus sulfometuron at 9.0 oz/acre were shorter in Fall 2009 and 2010 and had reduced leader lengths in Fall 2009. All other treatments at Gobles were similar to the untreated controls for height, leader length, stem diameter, and number of leader buds.

At Horton, trees treated with hexazinone plus sulfometuron at $9.0 \mathrm{oz} /$ acre were shorter in Fall 2009 and 2010 and had reduced leader lengths in Fall 2008-10 (Fig. 3). Trees treated with hexazinone plus sulfometuron at 6.0 and $7.5 \mathrm{oz} /$ acre were shorter in Fall 2008-10 and had shorter leader lengths in Fall 2008 and 2009. Trees treated with hexazinone plus sulfometuron at $4.5 \mathrm{oz} /$ acre were shorter in Fall 2008 and 2009. Trees treated with simazine plus oryzalin plus paraquat were shorter and had shorter leader lengths in Fall 2009 and 2010 and had smaller diameters in Fall 2009. The remaining treatments at Horton were similar to the untreated control for height, leader length, stem diameter, and number of leader buds.

WEED CONTROL WITH HEXAZINONE PLUS SULFOMETURON AND OTHER HERBICIDES. At Gobles, all preemergence treatments provided excellent weed control in June 2008 (Fig. 4). A few common ragweed and horseweed had emerged in various plots by 17 June. In July, hexazinone plus sulfometuron at all rates maintained control of quackgrass, common ragweed, and horseweed. By 7 Aug., quackgrass had begun to expand in all the plots. Common ragweed emerged in flumioxazin plots in greater numbers in July. Common ragweed control in the flumioxazin plots improved between July and August, apparently because it was outcompeted by the quackgrass. Weeds emerged in pronamide plus oxyfluorfen plots by late July.

In May 2009, all treatments provided excellent control of common milkweed (Asclepias syriaca), horseweed, and hoary alyssum at Gobles (Fig. 5). By July, horseweed had emerged in all the plots, with the $4.5-\mathrm{oz} /$ acre rate of hexazinone plus sulfometuron, flumioxazin, and pronamide plus oxyfluorfen-treated plots having the most horseweed. Rabbitfoot clover emerged in early July and was controlled by hexazinone plus sulfometuron at all rates. The other treatments gave fair to good rabbitfoot clover control. Common ragweed emerged by mid-July and was controlled by all rates of hexazinone plus sulfometuron. The other treatments also gave good common ragweed control.

In 2010, none of the preemergence treatments controlled horseweed in May (Fig. 6). In June, the untreated control and simazine plus oryzalin plus paraquat plots had the least horseweed. The horseweed in the untreated control plots probably was outcompeted by the rabbitfoot clover. In July, there was very little quackgrass and common ragweed in any of the plots. There were many horseweeds in the plots, which may have suppressed other weeds. The rabbitfoot clover had declined in the untreated and pronamide plus oxyfluorfen plots by mid-July.

At Horton in 2008, all the treatments provided excellent control of 


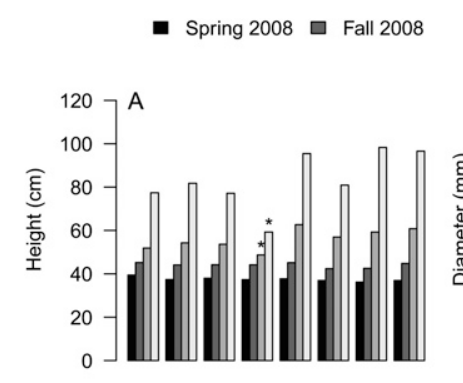

$\square$ Fall $2009 \quad \square$ Fall 2010
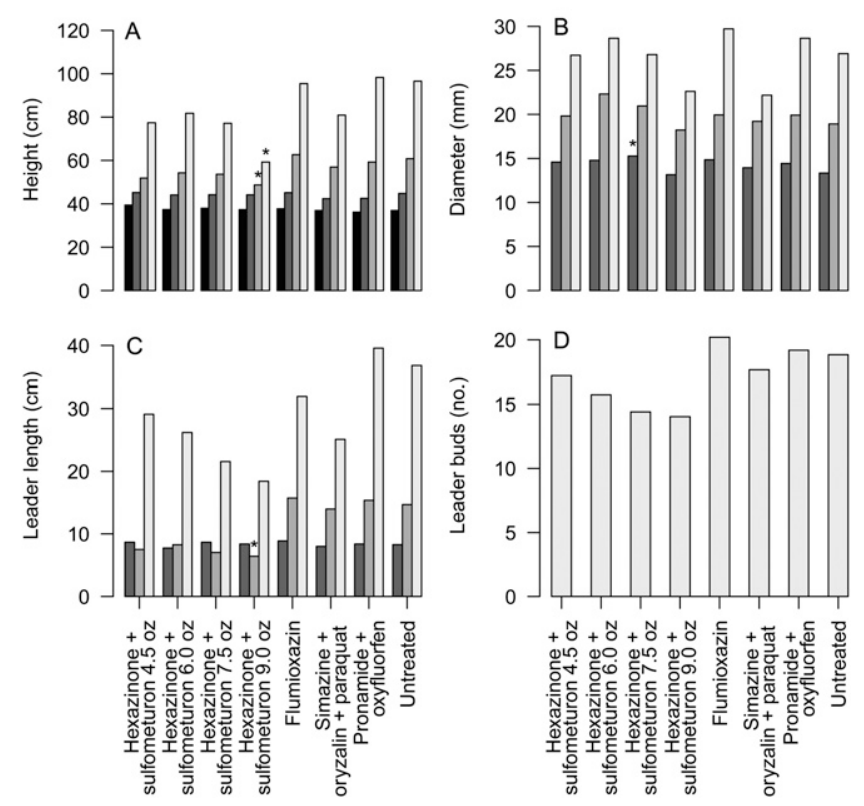

Fig. 2. Fraser fir height (A), diameter (B), leader length (C), and number of leader buds (D) at Gobles, MI for 2008-10. Application rates for hexazinone plus sulfometuron treatments are in ounces per acre. Each bar is the modeled value from three replicates $(n=3)$. Asterisks indicate that a treatment is significantly different from the untreated control for that specific time point $(P \leq 0.05)$. Significant differences were obtained using Tukey's post hoc test; $1 \mathrm{~cm}=0.3937$ inches, $1 \mathrm{~mm}=$ 0.0394 inches, $1 \mathrm{oz} / \mathrm{acre}=70.0532 \mathrm{~g} \cdot \mathrm{ha}^{-1}$.

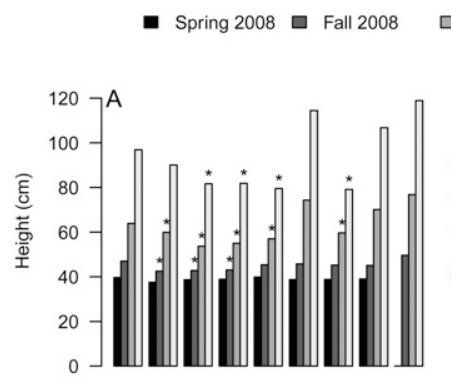

Fall $2009 \square$ Fall 2010
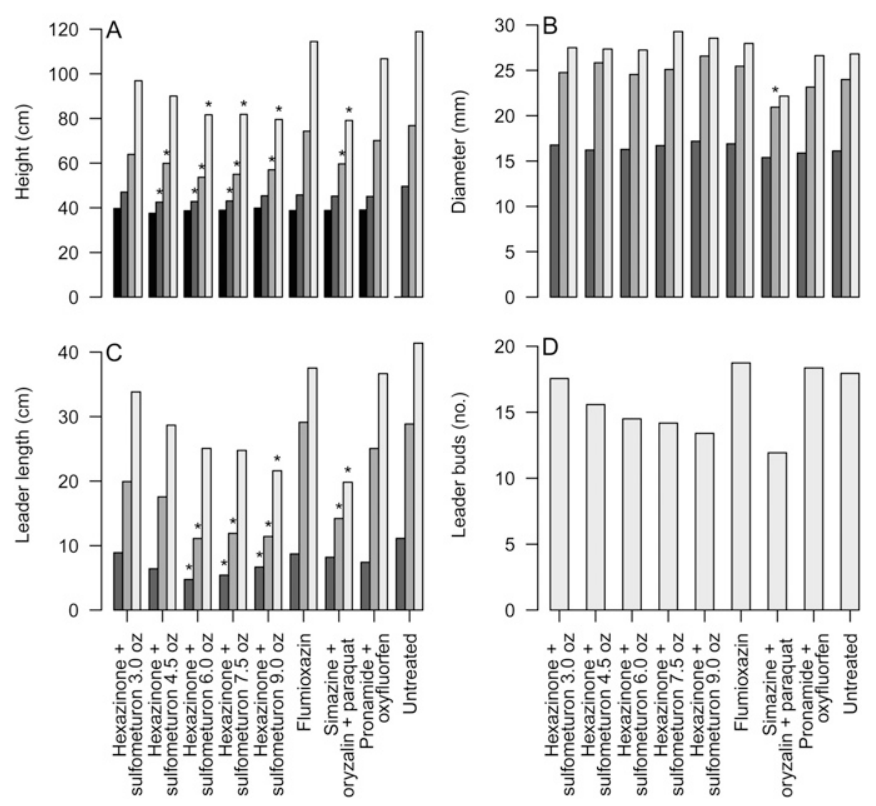

Fig. 3. Fraser fir height (A), diameter (B), leader length (C), and number of leader buds (D) at Horton, MI for 2008-10. Application rates for hexazinone plus sulfometuron treatments are in ounces per acre. Each bar is the modeled value from four replicates $(n=4)$. Asterisks indicate that a treatment is significantly different from the untreated control for that specific time point $(P \leq 0.05)$. Significant differences were obtained using Tukey's post hoc test; $1 \mathrm{~cm}=0.3937$ inches, $1 \mathrm{~mm}=$ 0.0394 inches, $1 \mathrm{oz} /$ acre $=70.0532 \mathrm{~g} \cdot \mathrm{ha}^{-1}$. yellow foxtail (Setaria glanca) (Fig. 7). In July, hoary alyssum and horseweed emerged in the plots and were not sufficiently controlled by flumioxazin. The 7.5- and 9.0-oz/acre rates of hexazinone plus sulfometuron provided $\approx 65 \%$ control of horseweed and complete control of hoary alyssum. Simazine plus oryzalin plus paraquat provided better horseweed control than the other treatments. Pronamide plus oxyfluorfen provided good control of hoary alyssum but no control of horseweed.

In May 2009, all treatments provided good control of yellow foxtail, hoary alyssum, and horseweed (Fig. 7). By September, the hexazinone plus sulfometuron at $3.0 \mathrm{oz} / \mathrm{acre}$, flumioxazin, and pronamide plus oxyfluorfen treatments had lost control of horseweed. Hexazinone plus sulfometuron at all rates provided complete control of hoary alyssum and almost complete control of common ragweed. Horsenettle (Solanum carolinense) appeared in the plots in 2009 , but it was suppressed by most of the herbicide treatments. The untreated plots had no horsenettle, probably because of heavy infestation of yellow foxtail and horseweed.

Hexazinone plus sulfometuron at all rates provided excellent control of hoary alyssum in June 2010, but provided poor control of horseweed (Fig. 7). Simazine plus oryzalin plus paraquat provided very good control of both weed species in June and flumioxazin and pronamide plus oxyfluorfen provided moderate control. By July, horsenettle emerged but was controlled $80 \%$ to $100 \%$ in most plots. Common ragweed and yellow foxtail were controlled by all treatments.

Hexazinone plus sulfometuron provided good control of most weeds through July of each year. Horseweed emerged in midsummer each year in the hexazinone plus sulfometuron plots. In June and July 2010, there were more horseweeds in the hexazinone plus sulfometuron plots (except $9.0 \mathrm{oz} /$ acre) than in the untreated and other treatments. Horseweed appears to germinate and grow well when there is minimal competition from other weeds. Hexazinone plus sulfometuron was less effective than the untreated treatments for horseweed control in 2010 , and was similar to the untreated plots in July 2008, May 2009, and 


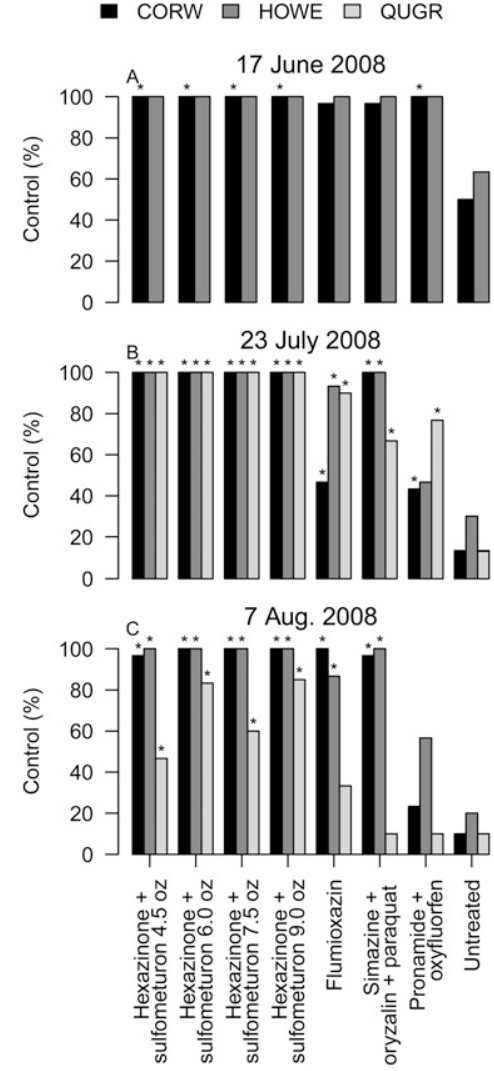

Fig. 4. Select weed control ratings for Gobles, MI, in 2008. Ratings were taken on 17 June (A), 23 July (B), and 7 Aug. (C) for common ragweed (CORW), horseweed (HOWE), and quackgrass (QUGR). Application rates for hexazinone plus sulfometuron treatments are in ounces per acre. Each bar is the modeled value from three replicates $(n=3)$. Asterisks indicate that a treatment is significantly different from the untreated control for that specific time point $(P \leq 0.05)$. Significant differences were obtained using Tukey's post hoc test; $1 \mathrm{oz} /$ acre $=$ $70.0532 \mathrm{~g} \cdot \mathrm{ha}^{-1}$.

Sept. 2009. The untreated controls often had a high predominance of one or two weeds, which outcompeted other species. In both Gobles and Horton, the untreated plots usually had few horseweeds. Horsenettle appeared at the end of 2009, after other weeds were controlled for nearly 2 years (Fig. 7 ). Flumioxazin provided good control of most weeds for 3 years. Flumioxazin suppressed horseweed early in the season, but horseweed emerged in flumioxazin plots by late summer.

The simazine plus oryzalin plus paraquat treatment caused visual fraser fir injury in 2008 and 2009 at Gobles and in 2009 at Horton.
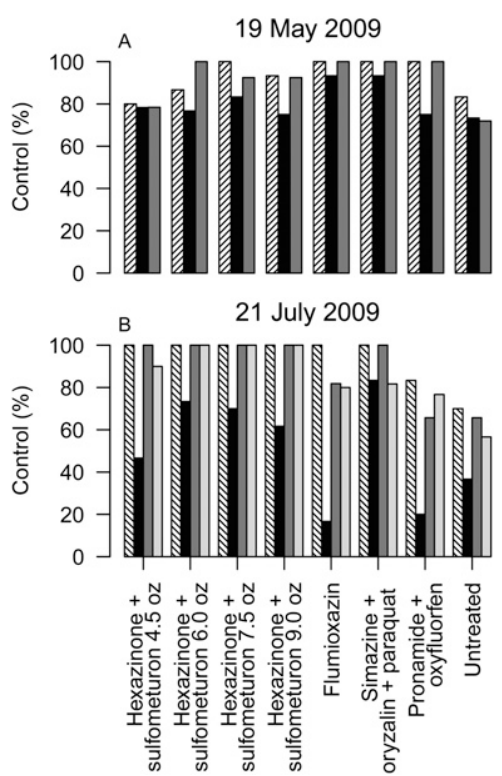

Fig. 5. Select weed control ratings for Gobles, MI, in 2009. Ratings were taken on 19 May (A) and 21 July (B) for common milkweed (COMW), common ragweed (CORW), horseweed (HOWE), hoary alyssum (HOAL), and rabbitfoot clover (RFCL). Application rates for hexazinone plus sulfometuron treatments are in ounces per acre. Each bar is the modeled value from three replicates $(n=3)$. Asterisks indicate that a treatment is significantly different from the untreated control for that specific time point $(P \leq 0.05)$. Significant differences were obtained using Tukey's post hoc test; $1 \mathrm{oz} /$ acre = $70.0532 \mathrm{~g} \cdot \mathrm{ha}^{-1}$.

Other researchers have reported moderate Christmas tree injury with simazine (White and Newton, 1990), but improved weed control usually resulted in larger trees at harvest. In our experiments, the herbicides were applied to dormant trees in the spring, and evidently there was sufficient plant uptake during the season to injure the young trees, reducing their height and leader lengths in 2009 and 2010. Growers may consider not using simazine for 1-2 years after transplanting fraser fir to avoid potential tree injury.

The untreated trees usually had plant height, leader length, diameter, and number of leader buds similar to the best herbicide treatments. If growers choose not to control weeds in the first years after field establishment, they may not lose time to harvest.

Richardson and Zandstra (2009) reported poor horseweed control with

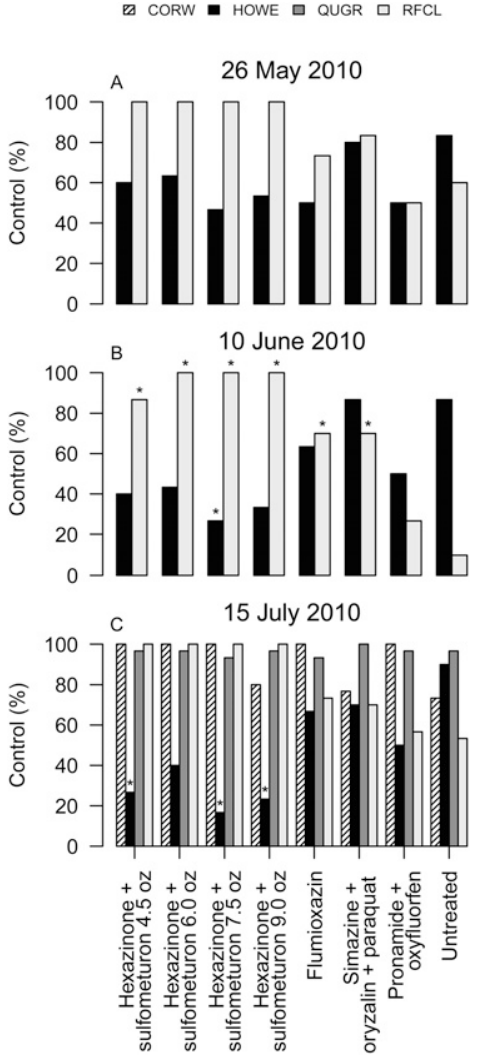

Fig. 6. Select weed control ratings for Gobles, MI, in 2010. Ratings were taken on 26 May (A), 10 June (B), and 15 July (C) for common ragweed (CORW), horseweed (HOWE), quackgrass (QUGR), and rabbitfoot clover (RFCL). Application rates for hexazinone plus sulfometuron treatments are in ounces per acre. Each bar is the modeled value from three replicates $(n=3)$. Asterisks indicate that a treatment is significantly different from the untreated control for that specific time point $(P \leq 0.05)$. Significant differences were obtained using Tukey's post hoc test; $1 \mathrm{oz} /$ acre $=$ $70.0532 \mathrm{~g} \cdot \mathrm{ha}^{-1}$.

$9.0 \mathrm{oz} /$ acre of flumioxazin. They suggested using a postemergence herbicide with flumioxazin for better weed control. Kuhns and Harpster (2005) suggested using hexazinone plus sulfometuron at rates of $9.0 \mathrm{oz} / \mathrm{acre}$ or lower to avoid tree injury. Results from our experiments indicate that rates of 4.5 to $7.5 \mathrm{oz} / \mathrm{acre}$ of hexazinone plus sulfometuron were safe on fraser fir and provided acceptable weed control, except for horseweed. Few herbicides control all weeds without incurring some crop injury, which usually is rate related. Horseweed tolerates many herbicides and can germinate anytime, 

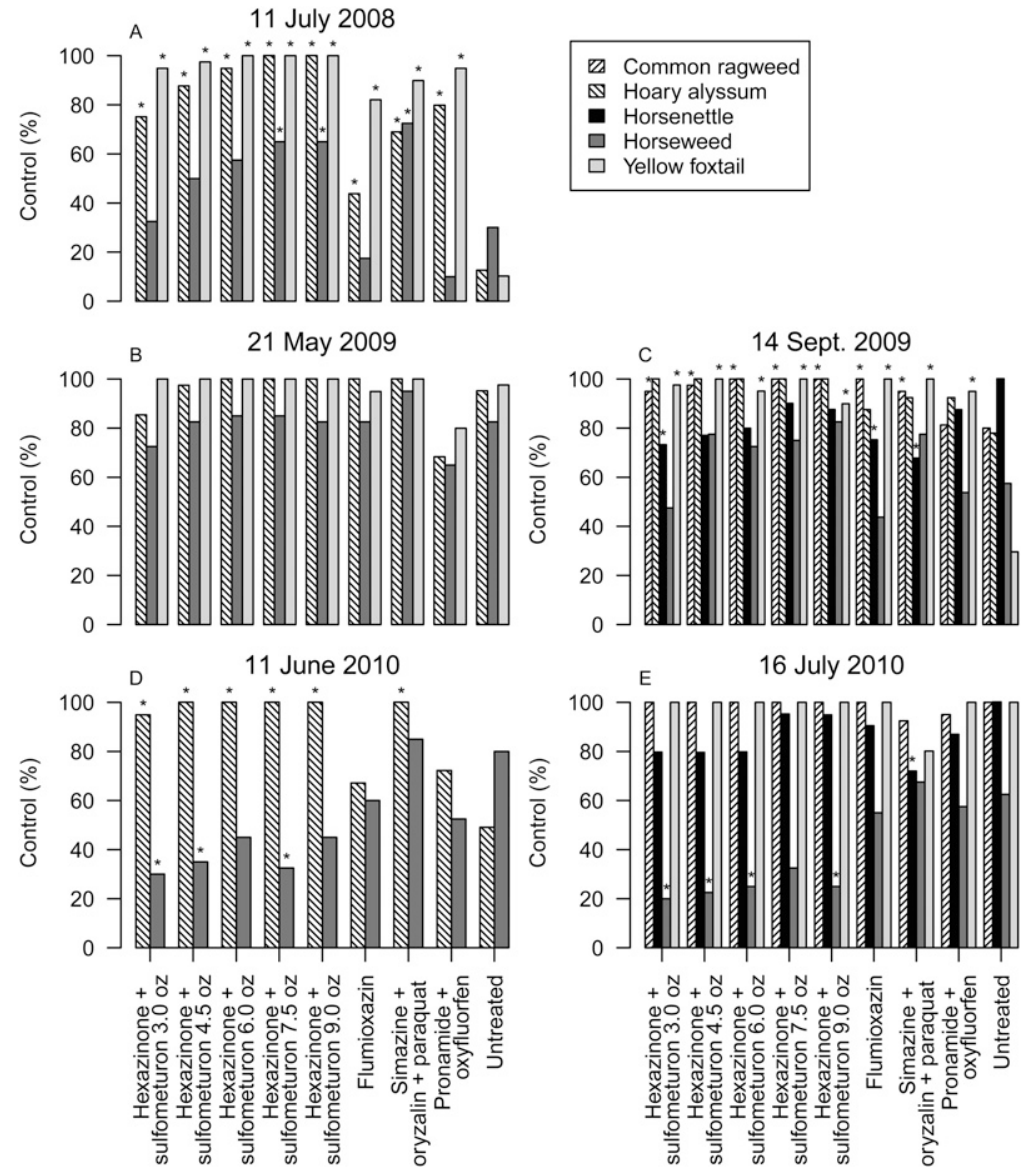

Fig. 7. Select weed control ratings for Horton, MI, in 2008-10. Ratings were taken on 11 July 2008 (A), 21 May 2009 (B), 14 Sept. 2009 (C), 11 June 2010 (D), and 16 July 2010 (E) for common ragweed (CORW), hoary alyssum (HOAL), horsenettle (HONE), horseweed (HOWE), and yellow foxtail (YEFT). Application rates for hexazinone plus sulfometuron treatments are in ounces per acre. Each bar is the modeled value from four replicates $(n=4)$. Asterisks indicate that a treatment is significantly different from the untreated control for that specific time point $(P \leq$ $0.05)$. Significant differences were obtained using Tukey's post hoc test; $1 \mathrm{oz} / \mathrm{acre}=$ $70.0532 \mathrm{~g} \cdot \mathrm{ha}^{-1}$.

especially after herbicides have dissipated in mid to late summer.

The hexazinone plus sulfometuron treatments provided good weed control but reduced fraser fir height significantly when used for 3 years at $9.0 \mathrm{oz} /$ acre at Gobles and at 6.0 , 7.5, and $9.0 \mathrm{oz} /$ acre at Horton. Simazine plus oryzalin plus paraquat reduced fraser fir height and leader length in 2009 and 2010. Flumioxazin was consistently safer than hexazinone plus sulfometuron on fraser fir and did not reduce height, leader length, stem diameter, or number of leader buds in any year at either location. Pronamide plus oxyfluorfen also was safe on fraser fir.

Despite some differences in the outcome of tree growth statistical comparisons (Figs. 2 and 3), the results at the two sites were similar in several ways. In general, increasing the rate of hexazinone plus sulfometuron decreased fraser fir height and leader length at both sites. The $9.0-\mathrm{oz} /$ acre rate of hexazinone plus sulfometuron caused reduced height and leader length at both locations. The 6.0and $7.5-\mathrm{oz} /$ acre rates also reduced height and leader lengths at Horton. There is no explanation for the increased hexazinone plus sulfometuron activity and reduced height at Horton, compared with Gobles. To avoid tree stunting, growers probably should not use more than $6.0 \mathrm{oz} /$ acre of hexazinone plus sulfometuron on recently established fraser fir plantings.

With experience under their local conditions, Christmas tree producers may use most of the preemergence treatments used in these experiments in new fraser fir plantings without concern for serious crop stunting or injury.

\section{Literature cited}

Ahrens, J.F. and M. Newton. 2008. Benefits of triazine herbicides in the production of ornamentals and conifer trees, p. 225-234. In H.M. LeBaron, J.E. McFarland, and O.C. Burnside (eds.) The triazine herbicides. Elsevier, Amsterdam, The Netherlands.

Akaike, H. 1974. A new look at the statistical model identification. Inst. Electrical Electronics Eng. Trans. Automatic Control 19:716-723.

Brown, J.H., M.A. Spetich, and R.B. Heiligmann. 1989. Effects of frequency of chemical weed control on growth and quality of Christmas trees. Northern J. Appl. For. 6:15-17.

DuPont Corp. 2009. DuPont ${ }^{\mathrm{TM}}$ Westar $^{\circledR}$. DuPont Corp., Wilmington, DE.

Gower, S.A., R.J. Richardson, and B.H. Zandstra. 2004. Survey of herbicide resistant weeds in Michigan Christmas tree plantations. Proc. North Central Weed Sci. Soc. 59:106. (abstr.).

Kuhns, L.J. and T.L. Harpster. 2005. Effect of the pre-mix combinations of Oust Extra and Westar on douglas and fraser fir. Proc. Northeastern Weed Sci. Soc. 59:48-50. (abstr.).

Lantagne, D.O. and M.R. Koelling. 1997. Effective herbicide use in Christmas tree plantations. Michigan State Univ. Ext. Bul. NCR-251.

Martin, M.J., S.K. Rick, D.D. Ganske, M.F. Holm, and R.G. Turner. 2004. Test results in eastern Christmas trees with a new blended product of sulfometuronmethyl and hexazinone. Proc. North Central Weed Sci. Soc. 59:107, (abstr.).

Michigan State University. 2013. Enviroweather: MSU Horticulture Teaching \& Research Center. 25 Feb. 2013. <http:// www.agweather.geo.msu.edu/mawn/>.

Muenscher, W.C. 1935. Weeds. Comstock Publ., Ithaca, NY.

Neal, J.C., W.A. Skroch, J.E. Derr, and A. Senesac. 1999. Weed control suggestions for Christmas trees, woody ornamentals, and flowers. North Carolina State Ext. Serv. Bul. AG-427.

Ott, R.L. and M. Longnecker. 2001. An introduction to statistical methods and data analysis. 5th ed. Duxbury, Pacific Grove, CA. 


\section{Research Reports}

Peachey, E., C. Landgren, and T. Miller. 2011. Weed and vegetation management in Christmas trees. Oregon State Univ. Bul. PNW-625.

Richardson, R.J. and B.H. Zandstra. 2006. Evaluation of flumioxazin and other herbicides for weed control in gladiolus. Weed Technol. 20:394-398.

Richardson, R.J. and B.H. Zandstra. 2009. Weed control in Christmas trees with flumioxazin and other residual herbicides applied alone or in tank mixtures. HortTechnology 19:181186.

Rose, R. and J.S. Ketchum. 2004. Interaction of initial seedling diameter, fertilizations and weed control on douglas fir growth over the first four years after planting. Ann. For. Sci. 60:625-635.

SAS Institute. 2008. SAS/STAT® 9.2 User's guide. SAS Institute Inc., Cary, NC.

Seifert, J.R. and K.E. Woeste. 2002. Evaluation of four herbicides and tillage for weed control on 1-0 planted tree seedlings. Northern J. Appl. For. 19:101-105.

U.S. Department of Agriculture. 2004. 2003 Agricultural chemical usage, nursery floriculture summary. U.S. Dept. Agr., Washington, DC.

White, D.E. and M. Newton. 1990. Herbaceous weed control in young conifer plantations with formulations of nitrogen and simazine. Can. J. For. Res. 20:16851689. 